\title{
THE METASTASES OF MYTH: LEGAL IMAGES AS TRANSITIONAL PHENOMENA \\ DESMOND MANDERSON
}

Professor Desmond Manderson

Humanities Research Centre

ANU College of Law

Australian National University

Canberra ACT 0200

AUSTRALIA

Email: Desmond.manderson@anu.edu.au

Tel: +61 (0)2 61970057

ABSTRACT. In times of transition and transformation, legal images metastasize. This idea can be usefully related both to Winnicott's theory of transitional objects and Barthes' theory of myth. But each tell only part of the full story. Barthes fails to fully account for the stabilizing effect of the reassuring signifier; Winnicott fails to fully account for the ideological adaptability - and implications - of the shifting signified. The legal image unites the iterability of the signifier and the polysemy of the signified, harnessing the affective intensity of the former to the cultural mobility of the latter. In this article, I propose to illustrate this insight by reflecting on two notable images of law that appeared at a moment of profound legal transformation, at the dawn of the early modern era. The images of 'blind justice' and 'sol justiciae' which the article discusses are both 'transitional myths', facilitating through modes of affect a legal journey into uncharted territory. Paying attention to these images and above all to their 
transformation over time, we can observe not only the process of legal transition at work, but the function of the image in its authorization and modalization.

KEYWORDS. blind justice; law and art; law and the image; myth; transitional objects.

\section{MYTH, IMAGE, AND TRANSITIONAL PHENOMENA}

In times of transition and transformation, legal images metastasize. This process, simultaneously one of movement and sameness, may properly be analyzed under the rubric of myth, but illustrates an important aspect which Roland Barthes, in his classic work on the subject, ignores. Myth, says Barthes, is a kind of meta-language. It takes the raw material of a sign - a combination of signifier and signified - and strips it of memory, knowledge, and history (Barthes 1957, pp. 115-7). Now denuded of particularity, the sign is transformed into an essence of some kind and combined with a new signified. It becomes 'frozen speech' - 'it stiffens, it makes itself look neutral and innocent' (p. 125). One well-known example, drawn from the cover of Life Magazine, shows a black soldier saluting the French flag during the Algerian war. The soldier and his blackness, divorced from their history and context, are drafted into the service of an ideological signified: the essence of 'nationhood'.

This is a kind of arrest, in both the physical and the legal sense of the term: French imperiality condemns the saluting Negro to be nothing more than an instrumental signifier, the Negro suddenly hails me in the name of French imperiality; but at the same moment the Negro’s salute thickens, becomes vitrified, freezes into an eternal reference meant to establish French imperiality... This is because myth is speech stolen and restored. Only, speech which is restored is no longer quite that which was stolen: when it was brought back, it was not put exactly in its place. It is this brief act of larceny. (p. 125)

For Barthes, the operation of myth is insidious because it is ideological, and ideological because it strips politics from speech. It transforms historical intention into a natural 
justification, 'making contingency appear eternal' and reducing human decisions to 'the simplicity of essences' (p. 142). Myth therefore is the status quo's greatest weapon, and the enemy of all social change. 'For the very end of myths is to immobilize the world: they must suggest and mimic a universal order which has fixed once and for all the hierarchy of possessions' (p. 155).

This is true, but only as far as it goes. The proposition that myth, at least in the modern West, benumbs critique, essentializing social inequality and tranquilizing social resistance, is persuasive. Myth speaks in the voice of eternity; it presents injustice as natural, as inevitable, as nothing more than how things are. But in some ways Barthes takes mythic language too much at face value. He treats it not just as a gesture of stability but as a force of stability. In the process he entirely misses one of the most vital characteristics of mythic speech and the images that animate them: their ability, precisely by invoking the rhetoric of eternity and essence, to surreptitiously advance the most dramatic of social changes. The end of myth, particularly in its more ideological manifestations, is emphatically not to 'immobilize the world'; only to appear to do so.

Barthes' failure to appreciate the ways in which myth is capable of facilitating social change by dressing it up in the frock of eternity, makes his structural analysis one-sided. He insists throughout 'Myth Today' that what is plastic is the signifier - the word or the sign or the image. By implication, the signified, that is myth's ideological content or meaning, remains unchanged. He focuses on the ways in which 'the smallest myth-signifier can generate the richest conceptual mythic structure' (p. 120). The relative emptiness of the signifier and the relative stability of the signified, he thinks, allows multiple signifiers to stand in for the same signifieds. Claude Levi-Strauss (e.g. 1979) starts from the same assumption. He too looks for an underlying coherence of signification beneath the superficial diversity of mythic signifiers - musical and architectural structures, stories, animal figures, topographic features, narratives, 
and so on. The search for constant signifieds beneath mobile signifiers is a pretty succinct characterization of structuralism.

But the opposite can equally be the case. Sometimes myth employs a stable signifier precisely so as to conceal a radical change in signification. The citation of signifiers - signs or images - conceals a transformation in meaning. We are dealing now with the historical movement of a myth over time. The image metastasizes. At any one moment we can say that its goal is to 'immobilize the world'. But over time the illusion of stasis is a strategy that works, on a meta-level, to legitimate certain social transformations. Barthes outlined an algebra of myth; its calculus, that is the study of how it changes over time, produces different results. Far from the plasticity of the signifier and the constancy of the signified, what emerges is the constancy of the signifier and the plasticity of the signified. The search for mobile signifieds beneath constant and iterable signifiers is a pretty succinct characterization of poststructuralism.

In political terms, likewise, Barthes treats 'the right' as a group that holds power in order to protect its economic and social control. In other words he sees its interests as always conservative. The language of myth and the forces of conservatism form a natural alliance because both strive to prevent social consciousness and sabotage social change. But a moment's thought will reveal that this is far too simplistic. In the past twenty years, for example, 'the right' has advanced a brutal agenda of social and economic change. Call it 'globalization' or 'neo-liberalism'. This political constellation has not been passive or conservative at all. Right-wing politics today still evokes mythologies of stability, nature, and essence. But this is not because it is opposed to social change, but in an effort to disguise it. There is no more iconic symbol of constitutional traditionalism in the US, for example, than the 'right to bear arms'; yet the interpretation of the Second Amendment is now exactly the 
opposite of its interpretation at any time in the first 200 years of its existence. ${ }^{1}$ The rhetoric of myth is a 'distortion' of history, a 'conjuring trick' of de-politicization; but here it works to actively engage in social change. The conservatism of conservatism is just another myth.

Neither is this an historical anomaly. At critical junctures throughout our legal and economic history, forces of inequality have been radical agents of change, despite the fact that they have tended to fight under the banner of mythic figures - nation, nature, tradition, empire, God, and so on. The industrial revolution, for example, and before that the emergence of the modern State, absolutist monarchies, legal and religious Reformation, and so on, were all accompanied by dramatic changes in legal, social, and economic forms. In these struggles, mythic representations actively facilitated certain kinds of change under the guise of maintaining essences, traditions, and natures.

Take the image of Queen Elizabeth. ${ }^{2}$ Her status as the Virgin Queen was, of course, a mythical rather than a biological statement. In painting after painting, she is depicted as ageless, white-faced, immobile. References to the Queen as a vestal virgin - holding a sieve to echo the story of Tuccia, or as the just virgin Astraea (Yates 1975) - are insistent and powerful. In the Ditchley Portrait (Gheeraerts 1592) and others, ${ }^{3}$ she strides the world like a colossus, the embodiment of her imperial ambitions. She is shown capable of commanding not just map and globe, territory and power. She is sovereign over light and dark itself, like God on the first day of Creation. Yet at the same time she is holding a fan and gloves, representing and insisting on her femininity. The Rainbow Portrait (Oliver 1600-02) likewise builds on this complex political

\footnotetext{
${ }^{1}$ See for example Subcommittee on the Constitution of the Committee on the Judiciary 1982; Levinson 1989; District of Columbia v. Heller 2008.

2 See in particular Strong 1969, 1977, 1987.

3 Other examples include George Gower, Plimpton Sieve Portrait, 1579; Metsys the Younger, Siena Sieve Portrait, 1583; Armada Portrait, c. 1588; Crispijn van de Passe, 1596.
} 
symbolism. But while political analyses of the cult of Elizabeth emphasize her virginity as an oath of fealty to her kingdom, that no man may mar her rule nor limit her sovereignty, the affective dimensions of this symbolism have been less often observed. There had been a uniquely powerful cult of the Virgin Mary in Anglo-Saxon England (Clayton 2003). It continued to exert an overwhelming influence right up until the Reformation when, 'in the rampant iconoclasm of the English Reformation, the cult of the Virgin Mary was decisively fractured' (Espinosa 2011, p. 1; see also Maunder 2008). The figure of Mary occupied a complex range of roles in pre-Reformation Catholicism, but central to them all was the emotional connection she afforded worshippers through the figure of her cherished motherhood. Her role of intercessor was founded on her position as mediator between god and humankind. From the thirteenth century on she became a pivotal figure inspiring deep devotion and love (Kristeva and Goldhammer 1985), and generating shrines and sites of pilgrimage, festivals, and untold poems and plays. Indeed, Barry Spurr describes Mariolatry as 'the most pervasive expression of Catholic Christianity in England' (2007, p. 1); its suppression the most conspicuous feature of the English Reformation. For Protestantism, Marian idolatry was anathema precisely because it was rooted in extra-textual traditions and the affective and aesthetic dimensions of belief. It was the epitome of the feminization and aesthetic decadence of Catholicism. Its destruction was a critical feature of the reformers' 'masculinization of piety' (Espinosa 2011, pp. 22-25).

Scholars dispute the relationship between the two virgins in sixteenth-century England. This disagreement hinges on whether or not Elizabeth was really 'a compensation for the psychological trauma of losing the Virgin as an object of worship' or rather 'a figurehead of militant nationalistic Protestantism' (Espinosa 2011, pp. 27-8). On the latter view what matters is how the virgin became a figure of sovereignty rather than how the sovereign became a figure of virginity. But the idea of the image as a transitional myth demonstrates that both sides of 
this argument are right, and both are necessary. The cult of Elizabeth was not simply a replacement of like for like. Elizabeth the Virgin Queen thoroughly inverted the meaning of the Virgin Mary, imbuing it with a wholly new set of signifieds conformable to Protestant, nationalist, and imperialist, ideology. But she successfully accomplishes this transition precisely because she is able to appropriate the existing signifier and exploit popular emotional ties to it. As a sublimated form of the Virgin Mary, Elizabeth facilitates the transference of an emotional fealty from the figure of the holy mother to the figure of the mother of the nation (Strong 1977, 1987; Yates 1975). Her portraits were particularly potent in a semiotic tradition still governed, at least unconsciously, by the logic of the Eucharist, which construed certain sacred objects not as mere representations of Christ but as filled with his actual presence. If Elizabeth became 'the portrait of the queen', to borrow Louis Marin's phrase (1988), it is because her image was Janus-faced, uniquely positioned simultaneously to recall, and to reinvest with new meanings, the trope of virginity.

Contrary to Barthes' emphasis on its multiplicity, the continuity of the signifier can be seen to be of utmost importance to this and other processes of ideological transubstantiation. The argument has something in common with the work of D.W. Winnicott, who introduced and pioneered the study of 'transitional objects' $(1953,1971) .{ }^{4}$ As many other writers have since drawn out, the phrase 'security blanket' is singularly appropriate. Transitional phenomena allow the child to cope with change, in the first instance by becoming accommodated to the temporary loss of their mother, for example when going to sleep or in a novel environment. The signifier stimulates a memory of presence that compensates for an experience of absence (Winnicott 2011, pp. 101-5). The child's relationship to some special symbolic object - a blanket or teddy bear, a familiar tune or poem - thus alleviates their anxiety

\footnotetext{
${ }^{4}$ For further discussion, see also Busch 1974; Winnicott 2011, chapter 5, pp. 99-125 (containing the slightly revised 1971 version of the original 1951 paper); Winnicott 1971, ch. 1.
} 
(Passman 1987; Coppolillo 1977; Wallendorf and Arnould 1988). Its repetitive availability, its capacity for immediate citation, comforts the child. As Winnicott (2011, p. 115) is at pains to point out, it is not in fact the object which is in transition but the user of it. The transitional object, like Piaget's 'assimilative schema', is a 'bridge' that enables the child to understand and respond to a changing external world. In this way it should be distinguished from a fetish, whose obsessive and repetitive character is a purely defensive posture against the onset of anxiety (Deri 1978, pp. 52-3; Dickes 1978, pp. 307-19). The transitional object, in contrast, is creative and enabling.

The possibility of applying the notion of transitional phenomena to the broader field of culture, has not gone unremarked (e.g. Modell 1970; Rudnytsky 1993). Winnicott and his followers recognized the role of aesthetics in the constitution of the world more persuasively than Freud. Winnicott (2011, p. 115) had already observed:

This intermediate area of experience, unchallenged in respect of its belonging to inner or external (shared) reality, constitutes the greater part of the infant's experience, and throughout life is retained in the intense experiencing that belongs to the arts and to religion and to imaginative living, and to creative scientific work.

We can begin to see that the idea of transitional objects captures a broad swathe of human practices of meaning-making. If the teddy bear is ‘the first not-me possession’ (Winnicott 1953, 1971), then burial rituals are the last. These too, in very many cultures, serve to relieve separation anxiety by incorporating treasured objects to comfort us as we embark on a deeply mysterious journey into an intransigent external reality (Grolnik 1978, p. 381).

Myth is, on a much grander scale, something like the 'security blanket' of a culture, a collection of images and scenes that simultaneously accommodate the individual to social structures, and invite their participation in them (Manderson 2003). The portrait of the queen can be understood in these terms. Elizabeth's reified and familiar effigy alleviated the pain caused by the absent mother of god. Her image was a security blanket, a reassurance against 
anxiety, but it was not a fetish. Under her eyes, new constellations of meaning were gaining traction, infusing the emotional satisfaction of the past with new meaning, combining the form of the old with the substance of the new. Thus the image of Elizabeth appropriated a familiar figure of devotion - essential, natural, irresistible - and propelled it along new paths. What impresses one is not that ideology 'immobilize[s] the world', but on the contrary that it mobilizes it so effectively, while giving the opposite impression. That is the role played by law's transitional objects.

Yet Barthes’ discussion of 'myth today’ offers a much less sanguine analysis of cultural symbols. Whereas Winnicott and his followers see security as a functional adaptation to the 'external world', Barthes sees instead a sickening complacency. That is the difference, perhaps, between psychology and sociology. For Barthes, the comforts of myth are overwhelmingly a 'distortion', ‘a trick', 'robbery’, or 'larceny'. So Winnicott's theory of transitional objects suffers from the obverse limitation to Barthes' theory of myth. Barthes fails to fully account for the stabilizing effect of the reassuring signifier; Winnicott fails to fully account for the ideological adaptability - and implications - of the shifting signified. The legal image unites the iterability of the signifier and the polysemy of the signified, harnessing the affective intensity of the former to the cultural mobility of the latter. In the sections that follow, I propose to illustrate the importance of this insight by reflecting on two notable images of law that appeared at a moment of profound legal transformation, at the dawn of the early modern era. Both were 'transitional myths', facilitating through modes of affect a legal journey into uncharted territory. Paying attention to these images and above all to their transformation over time, we can observe not only the process of legal transition at work, but the function of the image in its authorization and modalization. 


\section{BLIND JUSTICE}

[INSERT FIGURE 1 ABOUT HERE]

Figure 1: Fool Blindfolding Justice, in Sebastian Brant, Das Narrenschiff (woodcut, 1494)

(C) Beinecke Rare Book and Manuscript Library, Yale University. Permission to reproduce gratefully acknowledged.

The figure of blind justice is a relative newcomer to the iconography of Western law. ${ }^{5}$ In 1494 , the noted jurist Sebastian Brant published a collection of satirical poems called Das Narrenschif or The Ship of Fools, and commissioned several artists to illustrate it with a series of woodcuts (Brant 1494, 1944, 1971). Verse 71 is a crude satire, excoriating the corruption and cynicism of the legal profession. Brant's doggerel concludes:

He'll get much raillery uncouth,

Who fights like children tooth for tooth

And thinks that he can blind the truth. (Gillis 1971, p. 236) ${ }^{6}$

But the image, sometimes attributed to Albrecht Dürer (Figure 1; Brant 1944, p. 379; Panofsky 1995; Brant 1971, pp. xxv-vi), goes further in its critique than does Brant. It portrays not truth but justice being manhandled by a fool in a tricorn hat. We can rightly say that the figure of

\footnotetext{
${ }^{5}$ For other discussions, see Douzinas and Nead 1999; Jay 1999; De Ville 2011; Resnik and Curtis 2011, pp. 6290; Goodrich 2014, ch. 1.

${ }^{6}$ An alternative translation: 'Very often he feels the heckler's barbs / Who always quarrels like a child / And wants to make the truth blind.' (Leo Unglaub)
} 
'blind justice' was the artist's own invention. He emphasizes the animus of lawyers, actively blindfolding justice, the better to achieve their own foolish ends. Through the open window an urban vista can be glimpsed, recalling Ambrogio Lorenzetti’s ‘Allegory and Effects of Good Government', which since 1337 has held pride of place in the Palazzo Pubblico in Siena. ${ }^{7}$ But quite contrary to Lorenzetti's Aristotelian utopia, Brant's city is empty of humanity, and separated from the machinations of the law. The fool prepares justice for her role in some back room, like an actor's dressing room on opening night.

The appearance of this trope is not surprising. What is astounding is the speed with which it lost its satirical edge. The first edition of Césare Ripa’s Iconologia in 1593 notes that 'in the opinion of Plato, nothing escapes the eyes of Justice... and by the force of her gaze she penetrates to the base of all things' (1976). Ten years later, the earliest illustrated editions represent several aspects of justice, but only one of them - called 'worldly' or 'strict' justice was depicted blindfolded. But within a very short time, the Madonna bandita had become a ubiquitous symbol of abstraction and neutrality, and a generic statement of the judiciary's commitment to maintain a formal ignorance of personal circumstances. Even during the sixteenth century, official statues of blind justice - played straight, as it were - start to pop up (Resnik and Curtis 2011, pp. 62-75). As the inscription on Tübingen Town Hall explains, 'My eyes are bound so that rich and poor appear the same' (Resnik and Curtis 2011, pp. 62-75). By the early 1600s, something unprecedented seems to have overtaken the legal imaginary. The history of the image draws our attention to a complete inversion of established ideas, and pinpoints it in time.

What happened might be summed up in one word - modernity. Modernity came earlier to the law than to many other discursive formations. Harold Berman (1983, pp. 151-64) claims

\footnotetext{
${ }^{7}$ Lorenzetti 1337-39. For further discussions, see Mohr 2011; Skinner 1986, 1999; Rubinstein 1958; Nederman 1996; Meoni 2005.
} 
that law was the West's first real science, and the notion of blindness expressed its commitment to empirical neutrality centuries before it entered the language of scientific experiment. Ironically, it was the papacy that set it in motion. In 1075, Pope Gregory VII unilaterally declared the independence of the church from all secular authority. But at the same time, he announced a strikingly positivist set of reforms and arrogated to a structurally independent and hierarchical legal structure the authority to create new laws - jus novum (Tierney 1983, pp. 142-3; Blumenthal 1993).This was a momentous departure from the idea of law as divine, eternal, customary, or traditional. The great Norman kings of the twelfth century, Roger of Sicily, Frederick Barbarossa, and in England, Henry II, likewise understood monarchical power as essentially legislative and centralizing, advanced through a structure of legal regulation conceived as autonomous, posited, and written (Berman 1983, pp. 19-22, 80-96, 202-03). Thus was introduced the concept of 'rule by law', if not the rule of law. Increasingly, a professional legal and judicial class was needed to realize it (Berman 1983, pp. 405-57, 440-4).

The Reception of Roman law, first in the universities and then across the Holy Roman Empire, set in train a further process of centralization, textualization, bureaucratization, and regulation that left no corner of the realm untouched (Pennington 1993). Roman law expanded administrative and regulatory control, and profoundly altered the relationship between monarchical authority and justice. Princes began to think of themselves not as the guardians of legal principles of justice, but as its authors (Strauss 1986, pp. 150-1). Quite apart from the specific powers that might be taken away from local communities and jurisdictions in the name of Justinian or the 'common law of the empire', many people were troubled by the ineluctable rise of the legal profession which went with it. The fifteenth century saw increasing resistance, particularly in Germany, to the 'reformation' of the imperial civil law at the expense of local customary law (Strauss 1986; Vinogradoff 1961, pp. 139-42). Das Narrenschiff was one among many diatribes that displayed a deep anxiety concerning the growing power of 'written' or 
'learned' lawyers, whose essentially technical facility had made them biddable allies of the centralizing State - 'a guild of sovereignty-mongers', as Jacob Moser branded them (Strauss 1986, p. 142). The figure of blind justice appears for the first time only a few months before the establishment of the Rechtskammergericht as a central court of legal appeal across the Holy Roman Empire.

The Protestant Reformation was only the final chapter in a broad pattern of social and political change, in which the transformation of legal structures and institutions, and a corresponding dissociation between human law and divine justice, had sometimes been a lightning rod for discontent. Yet despite the Protestant movement's initial suspicion of modernity, its success in Northern Europe ultimately strengthened the hand of the State and entrenched the vehicle of written, formal law through which its power was exercised. Ironically, Luther's attack on the cosy relationship between the church and the law turned out to be a Trojan horse.

Where Lutheranism succeeded, the church came to be conceived as invisible, apolitical, a-legal; and the only sovereignty, the only law (in the political sense), was that of the secular kingdom... This Lutheran skepticism made possible the emergence of a theory of law - legal positivism - which treats the law of the state as morally neutral, a means and not an end. (Berman 1983, p. 29)

As Martin Jay notes (1999, p. 24), images of blind justice first emerge and proliferate in the public spaces of northern Europe, where Protestantism bit hardest and where the processes of modernization in law and the public sphere were most advanced. Protestantism's distrust of the power of emotion, feeling, and vision, proved to be thoroughly compatible with the arid and analytic sensibilities of modern law (Goodrich 1995; Douzinas and Nead 1999). Indeed, the notion of justice as blind was ideally placed to affirm Protestantism's intense fear of images (Belting 1997).

In fact, blind justice most recalls the figure of Synagoga, statues of which stood in many medieval churches as a symbol of the Old Testament and Judaism (Jacob 1994). Synagoga, 
aged and blindfolded, signified Judaism's stubborn refusal to open its eyes to the revelation of the New Testament (pp. 233-37). Synagoga is old where Ecclesia, the Church, is young, stooped where she is upright, blind where she sees all, pedantic where she is compassionate, law to her equity (Seiferth 1970). But in the years following the Reformation, blind synagogue - shorn of its anti-semitic associations - found a second life. As church and state became increasingly separate, the abstraction, the textual dogmatism, the downright legalism of Synagoga, in earlier times a theological atavism, came instead to constitute a secular value. The blindfold articulated a new relationship with the Christian church, now governed neither by a logic of progress and reconciliation (Ecclesia’s Gospel completing Synagoga’s Law), nor one of opposition and substitution (Gospel replacing Law), but rather of separation- Gospel, as Lucas Cranach’s painting (1529) so clearly illustrates, operating in a quite different sphere from the Law. The blindfold came to represent not a defect to be cured, but a temptation (towards visual sensuality) to be abjured. ${ }^{8}$ The medieval dinosaur did not become extinct after all. It evolved into the modern bird, and flew.

The myth of blind justice combines elements of the legal reformation that preceded it, and of which it was originally critical, with elements of the religious reformation that succeeded and substantially modified it. The image can be seen to hold together these two contradictory elements, uniting them into a new coherence. It accommodates itself to a profoundly new legal environment by incorporating references to the backward-looking critique within a new discourse of separation. Myths sublimate underlying tensions, in the strict sense of raising them

\footnotetext{
${ }^{8}$ Jacob 1994 concludes as follows: 'Le Moyen Age sentait la justice proche, familière. Il ne la voyait inquiétante qu'en ce qu’elle incorporait la proximité du châtiment et du salut, dont chacun devait se pénétrer. L’âge classique edifie une justice distante, inspirant la crainte parce qu'elle se veut autre... Le Moyen Age cherchait les fondements symboliques de la justice dans l'echange des regards croisés de tousses acteuers, les images leur donnant l'impulsion et le relais. L’age classique les éteint au profit d’une justice impénétrable.' (p. 245)
} 
to a higher plane, where they endow existing social relations with narrative legitimacy (see Levi-Strauss 1979, 1994; Freud 1918). The figure of blind justice is a myth of modern law in just this sense. It takes the underlying cultural oppositions that had been central to the contested emergence of modern law for centuries - between law and justice, letter and spirit, particular and general, local and universal, spiritual and temporal - and finds a new accommodation, transforming these dichotomies from the underlying critique of modern law to the condition of its authority.

The blindfold is a classic example of what I have described as a transitional myth - a security blanket for the eyes. The image does not just emerge during a critical time of transition, but ultimately enables it, representing in the same sign first one set of characteristics and then the opposite. In fact the same signifier undergoes not one but two declensions As Synagoga, the blindfold initially signified a legal fetish, unjust and repetitive. As Brant's fool, it translated a familiar religious critique into a secularizing context. Finally, under the complex influence of the Reformation, the blindfold came to celebrate the very separation it had initially condemned. The constancy of the signifier masked the fluidity of the signified. Stripped of its context and memory, the myth of the Madonna bandita proved infinitely pliable. By presenting herself as familiar, eternal and essential, she facilitated Europe's transition into legal modernity.

\section{SOL JUSTICIAE}




\section{Figure 1: Albrecht Dürer, Sol Justitiae (etching, 1500)}

\section{(C) The Trustees of the British Museum. Permission to reproduce gratefully acknowledged.}

Whether or not Brant's fool was drawn by Dürer, as Erwin Panofksy (1948) argued, it was a relatively crude foray into legal imagery. His Sol Justiciae (Figure 2; 1500) is far more richly suggestive and aesthetically rewarding, and displays many of the strengths that has made Dürer such an epochal figure in Western art. The peculiar posture of the figure, seated and with legs crossed, his gaze directed down and away, is in fact a common posture to signify judgment (Parallax 2008, pp. 51-2); the requirement that judges deliver their verdicts while seated goes back to Roman times. So Sol Justiciae is not an abstract ideal of justice, but a figure caught in the act of judgment. It provides a dazzling late synthesis of the whole pre-modern legal tradition that was then in decline, represented here through tropes of light and sun that prefigure a divine and transcendent visibility. Dürer's sol unites Christ and Apollo in the one persona (Panofksy 1943). This fusion had been sanctioned as early as the third century, the sun's cosmological centrality in the ancient world, transformed into a moral significance (pp. 259-60). Christ and Apollo, sun, god, and judge, are completed united in Dürer's portrayal. The lion indicates the summer solstice by reference to the zodiacal sign of Leo, while the circlet around the head combines Christ's halo and Apollo's corona. ${ }^{9}$ The blazing fire that emanates from him emits a merciless light that exposes the truth. It illuminates, sears, and burns. But his gaze is profoundly melancholy. In the Stanza della Signatura in the Vatican apartments, Raphael’s 'Justice’ (1511) holds a similar pose. She too is seated in judgment, eyes looking down and away, sword held high in her right hand, scales low in her left. But her mood is contemplative, other-worldly.

\footnotetext{
${ }^{9}$ See also Durer's image of Apollo1502; and of Resurrection 1497.
} 
Here, the sun of justice is wide-eyed and haunted. In the familiar language of the Bible, 'And said to the judges, Take heed what ye do: for ye judge not for man, but for the Lord, who is with you in the judgment' (II Chronicles 19:6). The judge's principal obligation is not to the king or the law but to God, whose justice he does and to whose judgment he must eventually subject himself. To give each their due is not a pleasure but a duty. The message Dürer conveys is of judgment as a burden, perhaps even as a curse. The lion, with all its coiled power, looks straight at us, but the sun of justice averts his gaze in sadness or disappointment. Dürer's Sol Justiciae discloses the intimate and affective bond between the act of judgment and the weight of justice, between the judge's earthly office and his accountability to the divine. It encapsulates centuries of iconography just as The Ship of Fools ushers in, albeit unwittingly, a radically opposed modern image - the former wide-eyed, emotional, all-seeing; the latter blind, clinical, unfeeling.

Under the pressures of legal modernity noted above, the trope of divine light, together with its emotional power and its cosmic resonances, did not disappear (see Goodrich 2014; Stolleis 2004). It too metastasized, the same signifier eliding a radical transformation. The eye of God, as Michael Stolleis puts it (2004, p. 36), 'migrated to the prince as the secular governor of God. His “omniscience”, as fictitious as it was, became the crucial basis of legitimation of the just content of laws'. The sovereign prince now laid claim to the all-seeing eye and the divine rays that illuminate the world. ${ }^{10}$ No doubt there is a shift in the use of such tropes. As Hans Belting points out (1997), the movement from pre-modern to modern is marked by the

\footnotetext{
${ }^{10}$ Examples discussed in Goodrich 2014 include emblems by Wither 1635, Bateman 1569, Presyler, and others.
} See also Zincgreff 1635, Bruck 1618, Sebastian de Covorrubius Orozco, 1613, Aneau 1565, all in Henkel \& Schone 1967. 
transformation of the function of images from icons whose meaning is simply present, like an aura, to artworks whose meaning requires (and is therefore subject to) interpretation. Reading becomes metaphorical and indirect rather than theological and direct. The image of the sun does not manifest what the sovereign 'is' but describes what he 'is like'. Nonetheless these newly-reconstituted symbols were rendered immeasurably more powerful by the reflected light of their divine predecessors. Gilt by association.

[INSERT FIGURE 3 ABOUT HERE]

Figure 3: Frankfurt Calendar (woodcut, 1547)

\section{Originally reproduced in Erwin Panofksy, Meaning in the Visual Arts (Princeton University Press, 1948), fig. 84 between pp. 170-71.}

The afterlife of Sol Justiciae itself presents a perfect example of the efficacy of the constant signifier to metastasize in this way, and thus to document in visual form the work of time in law. The 1547 Frankfurt Calendar shows one of many sixteenth century copies of Dürer's image. ${ }^{11}$ Its indebtedness to the original is obvious. Far more telling than the similarities between the two illustrations, however, are the differences. Fifty years after Dürer’s original, the sun of justice has metamorphosed into the sovereign - instead of a sword, a scepter; instead of scales of justice, an orb. Now the lion looks away and the sovereign meets our gaze. Indeed, the figure of sovereignty literally makes a spectacle of himself, his legs wide apart, his eyes directly engaged with ours. The naked cross-legged humility of the Sol has been replaced by an aggressively phallic arrogance. The sun too, or at least a star, has gravitated

\footnotetext{
${ }^{11}$ Panofsky 1995, p. 265 alludes to it in a footnote (n. 84), but does not appear to fully appreciate its implications.
} 
from head to groin, from mind to will, and from a burdensome duty to a compelling desire. Solar power has turned from a righteous agent of the divine into a rightful possession of the State; the difference between righteous and rightful is the difference between a claim which depends on the quality of the act and a claim which depends on the identity of the actor. There is all the difference in the world - in ideology, rhetoric, and orientation - between a righteous king and a rightful king, between, say, Saint Louis or Louis the Pious or Louis the Just, and Louis XIV, the Sun King. The image discloses with remarkable clarity how quickly and in what ways Dürer’s figure had become a transitional myth whose citation evoked the past while inaugurating the future. Sovereignty appropriated and embodied the totalitarian potential of the discourse of sunlight, just as it seized the whole theological structure of the Middle Ages (Kantorowicz 1965, pp. 157 ff., 382 ff.; 1997). ${ }^{12}$ The Frankfurt Calendar transforms an image of the irresistible force of transcendent justice into an image of the irresistible force of immanent laws.

Again, Sol Justiciae has undergone a double declension. Dürer's original engraving legitimated medieval Christian ideas of legality by citation from the ancient Greeks. Later copies legitimated early modern ideas of sovereignty by citation from Christian iconography. We saw the same pattern in relation to the figure of blind justice. There too we noted two successive shifts in signification, first from a theological to a secular context, and then from a critique of separation to an ideology of it. Blind justice came to valorize modern ideas of legality by citation from Protestant critiques. In each case, the backward-looking gestures of the image offered rhetorical and psychological continuity, without arresting substantive or structural change. As transitional myths, they operated on two registers at once, transporting the discourse and the sensibility of one period, in the interests of another. In the case of both

12 Perhaps it is worth noting that, after the Copernican revolution, the status and meaning of the sun itself had changed in important ways. 
sets of images, the constant mythic signifier masked and justified radical changes in legal theory and social ordering. Just so, William Blackstone's myth of the common law as proceeding from 'immemorial usage' (1830, Section 3) and filling legal space, at least according to Oliver Wendell Holmes’ characterization, like some 'brooding omnipresence in the sky’ (Southern Pacific Co. 1917, p. 222), imparted a mythic continuity to legal practices that were, in point of fact, notable for their fluidity and adaptability.

Winnicott helps you to appreciate how deeply embedded these symbolic and affective processes are in human life. But Barthes helps you to maintain your critical distance from them. The security blanket offers the child the talisman of an authority figure, allowing him or her to adapt to their absence, a new context, or even a new regime. If that sounds like it might be traumatic or illusory, it is because sometimes it is. The myths instantiated by legal images can be seen to do much the same things. They too reify talismans of authority in order to allow the legal system to accommodate their absence, a new context - even a new legal regime. If that sounds like it might be an ideological sleight of hand that is because sometimes it is. By tracing the metastases of legal images over time, we can observe with remarkable clarity, the seismic shifts of legal transitions. But these images do not merely document structural, conceptual, and emotional changes in social relationships to law. They also actively participate in them. The dynamic they establish between signifier and signified, continuity and transfiguration, are critical elements in how legal change takes place, then and now. By incorporating these perspectives, it is hoped that we can develop not just an algebra but a calculus of legal images - a heightened attentiveness to the visual representation and differentiation of legal change over time.

\section{REFERENCES}


Barthes, Roland. 1972. Myth Today. In Roland Barthes. 1972. Mythologies, trans. Annette Lavers. London: Jonathan Cape.

Belting, Hans. 1997. Likeness and presence: A history of the image before the era of art. Chicago: University of Chicago Press.

Berman, Harold. 1983. Law and revolution: The foundation of the western legal tradition. Cambridge Mass: Harvard University Press.

Blackstone, William. 1830. Commentaries on the laws of England. London: Collins \& Hannay.

Blumenthal, Uta-Renate. 1993. History and tradition in eleventh-century Rome. The Catholic Historical Review 79.2: 185-196.

Brant, Sebastian. 1494. Das Narrenschiff. Basel. On line accessible http: http://digital.lib.uh.edu/collection/p15195coll15

Brant, Sebastian. 1944. The ship of fools, trans. \& ed. Edwin Zeydel. New York: Columbia University Press.

Brant, Sebastian. 1971. The ship of fools, trans. \& ed. William Gillis. London: Folio Society. Busch, Fred. 1974. Dimensions of the first transitional object. The Psychoanalytic Study of the Child 29(21) 5-229.

Clayton, Mary. 2003. Cult of the Virgin Mary in Anglo-Saxon England. Cambridge: Cambridge University Press.

Coppolillo, Henry. 1977. The transitional phenomenon revisited. Journal of the American Academy of Child Psychiatry 15.1: 36-48.

Cranach, Lucas. 1529. Law and Grace. Tempera on linden wood, $82.2 \mathrm{~cm} \times 118 \mathrm{~cm}$. Museum Scholss Friedenstein.

De Ville, Jacques. 2011. Mythology and the images of justice. Law and Literature 23: 324. 
Dickes, Robert. 1978. Parents, transitional objects, and childhood fetishes. In Between reality and fantasy - Winnicott's concept of transitional objects and phenomena, eds.

Grolnik, Simon and Leonard Barkin. Northvale NJ: Jason Aronson, 307-319.

District of Columbia v. Heller. 2008.128 S. Ct. 2783 (United States Supreme Court).

Douzinas, Costas and Linda Nead, eds. 1999. Law and the image: The authority of art and the aesthetics of law. Chicago: The University of Chicago Press.

Dürer, Albrecht. 1497. Resurrection. Woodcut.

Dürer, Albrecht. 1499. Sol Justitiae. Engraved print.

Dürer, Albrecht.1502. Apollo. New York: Metropolitan Museum of Art. Engraving.

Espinosa, Rubin. 2011. Masculinity and Marian efficacy in Shakespearean England. Farnham: Ashgate.

Freud, Sigmund. 1918. Totem and taboo, trans. A. A. Brill. New York: Moffat, Yard \& Co. Gheeraerts the Younger, Marcus. c. 1592. The Ditchley portrait. London: National Portrait Gallery. Oil on canvas, 2413 mm x 1524 mm.

Goodrich, Peter. 1995. Oedipus Lex: Psychoanalysis, history, law. Berkeley: University of California Press.

Goodrich, Peter. 2014. Legal emblems and the art of law. New York: Cambridge University Press.

Gower, George. 1579. Plimpton Sieve portrait. Oil on panel, 104 cm x 76 cm.

Grolnik, Simon and Leonard Barkin, eds. 1978.Between reality and fantasy - Winnicott's concept of transitional objects and phenomena. Northvale NJ: Jason Aronson

Grolnik, Simon. 1978, Etruscan burial symbols and the transitional process. In Between reality and fantasy - Winnicott's concept of transitional objects and phenomena, eds. Grolnik, Simon and Leonard Barkin. Northvale NJ: Jason Aronson, 379-410. 
Henkel, Arthur, and Albrecht Schone. 1967. Emblemata - Handbushzursinnbildkunst des xvi. und xvii. Jahrhunderts. Stuttgart: JB Metzlersche.

Jacob, Robert. 1994. Images de la Justice. Paris: Léopard d'Or.

Jay, Martin, 1999. Must justice be blind? In Law and the image: The authority of art and the aesthetics of law, Douzinas, Costas and Linda Nead, eds. Chicago: The University of Chicago Press, 19-35.

Kantorowicz, Ernst. 1957. The king’s two bodies. Princeton: Princeton UniversityPress.

Kantorowicz, Ernst. 1965. Selected studies. Locust Valley, NY: JJ Augustin (Princeton Institute of Advanced Studies).

Kristeva, Julia, and Arthur Goldhammer. 1985. Stabat Mater. Poetics Today 6: 133-52.

Levinson, Sanford. 1989. The embarrassing second amendment. Yale Law Journal 99: 637659.

Lévi-Strauss, Claude. 1975. The raw and the cooked: Introduction to a science of mythology, trans.John Weightman. New York: Harper \& Row.

Levi-Strauss, Claude. 1979. Myth and meaning, trans. Wendy Doniger O'Flaherty. New York: Schocken Books.

Lorenzetti, Ambrogio.1337-39. Allegory of good government, allegory of bad government, effects of bad government in the city, effects of good government in the city and effects of good government in the country. Siena: Palazzo Pubblico. Frescoes.

Manderson, Desmond. 2003. From hunger to love. Law and Literature 15: 87.

Marin, Louis. 1988. Portrait of the king, trans. Martha Houle. Minneapolis: University of Minnesota Press.

Maunder, Chris, ed. 2008. The origins of the cult of the Virgin Mary. New York: Burns \& Oates. 
Melanie Wallendorf and Eric J. Arnould. 1988. 'My favorite things': A cross-cultural inquiry into object attachment, possessiveness, and social linkage. Journal of Consumer Research 14: 531-547.

Meoni, Maria Luisa. 2005. Utopia and reality in Ambrogio Lorenzetti’s good government. Florence: Edition IFI.

Metsys the Younger, Quentin. 1583. Siena Sieve portrait. Oil on panel.

Mohr, Richard.2011. The Christian origins of secularism and the rule of law. In law and religion in public life, Hosen, Nassan and Richard Mohr, eds. Abingdon: Routledge, 34.

Nederman, Cary. 1996. The meaning of ‘Aristotelianism’ in medieval moral and political thought. Journal of the History of Ideas 57: 563-585.

No author. 2008. The omnipresent eye of the judge - juridical evidence in Albrecht Dürer. Parallax 14, no. 4: 42-54.

Oliver, Isaac (attrib.). 1600-1602. Rainbow portrait. Hatfield: Hatfield House. Oil on canvas, $127 \times 99.1 \mathrm{~cm}$.

Panofsky, Erwin. 1948. Albrecht Dürer, 2 vols. Princeton NJ: Princeton University Press. Panofsky, Erwin. 1995. Meaning in the visual arts: views from the outside: a centennial commemoration of Erwin Panofsky (1892-1968),Irving Lavin,ed. Princeton, NJ: Princeton University Press.

Passman, Richard. 1987. Attachments to inanimate objects: Are children who have security blankets insecure? Journal of Consulting and Clinical Psychology 55.6: 825.

Pennington, Kenneth.1993. The prince and the law, 1200-1600 Berkeley: University of California Press.

Raphael. 1511. Justice, from Cardinal and theological virtues. PalazziVaticani: Stanza della Signatura. Tondo. 
Resnik, Judith and Dennis Curtis. 2011. Representing justice. New Haven: Yale University Press.

Ripa, Cesare.1976 [origin. 1593, 1603] Iconologia, 2 vols. New York, Dover.

Rubinstein, Nicolai. 1958. Political ideas in Sienese art: The frescoes by Ambrogio Lorenzetti and Taddeo di Bartolo in the Palazzo Pubblico. Journal of the Warburg and Courtauld Institutes 21: 179-207.

Rudnytsky, Peter, ed. 1993. Transitional objects and potential spaces: Literary uses of D.W. Winnicott. New York: Columbia University Press.

Seiferth, Wolfgang. 1970. Synagogue and church in the Middle Ages: Two symbols in art and literature, trans. Lee Chadeayne. New York: Ungar.

Skinner, Quentin.1999. Ambrogio Lorenzetti's Buon Governo frescoes: Two old questions, two new answers. Journal of the Warburg and Courtauld Institutes 62: 1-28.

Skinner, Quentin.1986. Ambrogio Lorenzetti: The artist as political philosopher. Proceedings of the British Academy 72: 1-56.

Southern Pacific Co. v. Jensen. (1917). 244 U.S. 205 (United States Supreme Court).

Spurr, Barry. 2007. The Virgin Blest: The Virgin Mary in English poetry. London: Palgrave Macmillan.

Stolleis, Michael. 2004. The eye of the law. Abingdon: Birkbeck Law Press.

Strauss, Gerald. 1986. Law, Resistance and the State: The opposition to Roman law in Reformation Germany.Princeton NJ: Princeton University Press.

Strong, Roy. 1969. The English Icon: Elizabethan and Jacobean Portraiture. London: Routledge \& Kegan Paul.

Strong, Roy. 1977. The Cult of Elizabeth.London: Thames and Hudson.

Strong, Roy. 1987. Gloriana: The Portraits of Queen Elizabeth I.London: Thames and Hudson. 
Subcommittee on the Constitution of the Committee on the Judiciary(Orrin Hatch, Chair). 1982. The Right to Keep and Bear Arms.97 $7^{\text {th }}$ Congress, $2^{\text {nd }}$ Session, S. Doc. 2807. Susan Deri. 1978. Transitional Phenomena. InBetween Reality and Fantasy - Winnicott's Concept of Transitional Objects and Phenomena, Grolnik, Simon and Leonard Barkin, eds. Northvale NJ: Jason Aronson, 43-60.

Tierney, Brian, ed. 1983. The Middle Ages, Vol. I: Sources of Medieval History, 4th ed.New York: Knopf.

Van de Passe, Crispijn. 1596. Engraving of Queen Elizabeth.

Vinogradoff, Paul. 1961. Roman Law in Medieval Europe.Oxford: Clarendon Press.

Winnicott, Donald Woods. 1953. Transitional Objects and Transitional Phenomena—A Study of the First Not-Me Possession.International Journal of Psycho-Analysis34: 89-97.

Winnicott, Donald Woods. 1971. Playing and Reality.London: Psychology Press.

Winnicott, Donald Woods. 2011.Reading Winnicott,Lesley Caldwell and Angela Joyce, eds. Hove: Routledge.

Yates, Frances. 1975. Astraea: The Imperial Theme in the Sixteenth Century.London and Boston: Routledge and Keegan Paul. 